\title{
LEGAL APPLICATION OF THE OFFENCE OF MURDER AND EUTHANASIA IN NIGERIA
}

\author{
Sani Ibrahim Salihu \\ School of Law, UUM COLGIS Universiti Utara Malaysia \\ E-mail: sisalihu.pcl@buk.edu.ng \\ Yuhanif Yusof \\ School of Law, UUM COLGIS Universiti Utara Malaysia \\ E-mail: yuhanif@uum.edu.my \\ Rohizan Halim \\ School of Law, UUM COLGIS Universiti Utara Malaysia \\ E-mail: rohizan@uum.edu.my
}

\begin{abstract}
Euthanasia is one of the concepts that stifled debate among academics, lawyers, religious scholars and even politicians. The reason being that it is killing human being although for compassionate reason, and with voluntary consent of the victim. Opponents of legalizing it, rely on the fear of slippery slope, sacred nature of life and question of inheritance. Despite the aforementioned factors, some countries legalised it while it remains a crime in the majority of other countries including Nigeria. We wrote this paper with the aim of highlighting and reinforcing the prohibition of the practice using Nigerian laws. Doctrinal method was employed to achieve the above objectives. In the process both primary and secondary legal materials were fully considered. The scope of the paper was limited to substantive provisions of both the penal code and the criminal code of Nigeria respectively. The aforementioned laws deal with the offence of murder by conduct or omission. However, there is no mention of the direct act of euthanasia, but from the reading of the laws inference can be drawn relating to withholding and withdrawing medical treatment leading to death. The finding of the paper is that although there is an elaborate provision regarding the prohibition of euthanasia under the criminal code, the law is not so adequate under the penal code and both laws are independent of themselves. Since both laws are applied at different geopolitical zones in Nigeria, the inadequacy of the laws will affect the administration of criminal justice in Nigeria. The paper therefore suggests an amendment to the penal code to fill the gap it has created.
\end{abstract}


Keywords: Euthanasia, Physician assisted suicide, Slippery slope, Murder, Nigeria.

Abstrak: Euthanasia telah menimbulkan konflik antara ahli akademik, peguam, tokoh agama dan juga ahli politik. Ini adalah kerana ia mematikan atau membunuh manusia sekalipun dilakukan atas dasar simpati dan dengan persetujuan mangsa. Pihak yang menentang euthanasia berpegang kepada faktor-faktor 'slippery slope', kesucian nyawa dan isu peninggalan. Walaupun begitu, terdapat negara yang mempraktikkan euthanasia manakala negara yang tidak berbuat demikian adalah kerana mengganggap ia sebagai satu jenayah termasuklah Nigeria. Artikel ini bertujuan untuk membincangkan berkaitan larangan perlaksanaan euthanasia berdasarkan undang-undang yang ada di Nigeria. Kaedah doktrinal digunakan untuk mencapai objektif kajian. Kedua-dua data primer dan sekunder turut digunakan dalam proses ini. Skop kajian pula hanya memfokuskan kepada peruntukan undang-undang ada dalam kanun keseksaan dan kanun jenayah. Undang-undang ini ada kaitan dengan kesalahan membunuh sama ada melalui melakukan sesuatu perbuatan atau ketinggalan. Walaupun tidak dinyatakan secara langsung, tetapi perbuatan menahan dan menarik balik rawatan perubatan yang membawa kepada kematian boleh dianggap sebagai euthanasia. Dapatan kajian menunjukkan bahawa walaupun terdapat peruntukan berhubung larangan terhadap euthanasia di bawah kanun jenayah, tetapi ia tidak mencukupi di bawah kanun keseksaan dan kedua-dua undang-undang ini adalah bebas daripada satu sama lain. Memandangkan kedua-dua undangundang ini digunakan di zon yang berbeza di Nigeria, kelemahan undang-undang ini akan mempengaruhi pentadbiran keadilan jenayah di Nigeria. Oleh itu, artikel ini mencadangkan pindaan dilakukan kepada kanun jenayah bagi mengatasi masalah ini.

Kata Kunci: Euthanasia, 'Physician assisted suicide', 'Slippery slope', Bunuh, Nigeria.

\section{INTRODUCTION}

Euthanasia is a concept that cuts across many disciplines including medicine, sociology, political science and even criminology. Its controversy passes all societies and time, particularly in Europe and 
America where agitation for human rights gains more acceptances. This makes the concept to be linked to human rights including the right to life, family and privacy. However, because the concept is related to suicide, situations arise where the person lacks the capacity to take his life and he needs the assistance of an expert, in this case a doctor, who at the same time contradicts the ethics of his profession and the code of conduct. Where then is the view of the physician, assisting or taking the life of his patient for compassionate reasons? The criminal aspect of his action will not allow him to go scot-free. This article will look at the criminal responsibility of physicians attempting to relief their patients from pain due to terminal illness for compassionate reasons, popularly known as euthanasia or assisted suicide.

\section{CONCEPTUAL DEFINITIONS}

\section{Euthanasia}

Euthanasia comes from the Greek Word "Eu" which means Good and "Thanatos" meaning death. It is referred to as good death. ${ }^{1}$ Euthanasia is an intentional or deliberate act or omission to bring the life of a patient to an end by a physician in order to relieve him from pain. Euthanasia is usually mistaken as assisted suicide, although they are different in all ramifications.

According to $\mathrm{Buka}^{2}$ an individual may legally end his life through whatever means, knowing fully that his action will result in death; this is called suicide. A similar act could be done with the assistance of third party, which is call assisted suicide. ${ }^{3}$ It is generally believed that there is a difference between euthanasia and physician assistedsuicide. In euthanasia, a physician carries the act or omits to act which leads to death, while in the case of assisted suicide, a physician only assists in the killing but the patient does the act himself. It is

Ebrahim Nagus. (2012). The ethics of euthanasia. Australian Medical Student Journal (3) 2.

2 Buka Paul. Patient's right law and ethics for nurses: A Practical guide London: Hdder education, 2008.

3 Paterson Craig. Assisted suicide and euthanasia: A natural law ethics approach. Cornwall: TJ International Limited, 2008 p.11. 
important to note that involving a third party, usually a physician, is the key difference. ${ }^{4}$

According to the World Health Organization (WHO) in 2004 euthanasia and assisted suicide were two different concepts. In assisted suicide somebody is killing himself with the assistance of another, who may provide skills, means or both. While euthanasia is a deliberate act by somebody to painlessly put another to death or failing to prevent death from the natural cause of death in a terminal illness. ${ }^{5}$ According to this definition WHO accepted the withdrawal of life support and treatment to be part of euthanasia which contradicted some decisions of the European Court of Human Right. ${ }^{6}$ This issue will be addressed by the paper.

\section{Types of Euthanasia}

A brief discussion of the type of euthanasia is very crucial because it will be part of the discussion of this article whether euthanasia strictor senso is unlawful and a crime or the criminality should be relaxed in some circumstances or some types of euthanasia.

Voluntary Euthanasia is the ending of a patient's life by another at the patient's request. Some scholars call it Voluntary Active Euthanasia because it is a deliberate act, usually through the intentional administration of lethal drugs, to end an incurably or terminally ill patient's life. ${ }^{7}$ Simply, a patient requests and consents to his life being shortened. It is voluntary because the patient exercises his autonomy and self-determination to ask for it.

Non-voluntary euthanasia is the opposite of the voluntary one. Physicians here administer any substance with the aim of shortening life without the consent of the patient, may be because the patient is in a comatose or is incapable of giving consent. Here there is a problem since no medical treatment will be carried out without consent; where the patient does not consent, it will create a serious

Centre for Bioethics. End of life care: An over view, 2005.

World Health Organisation. A glossary of terms of community health care and services for older persons, 2004.

6 Strinic Visnja. Argument in support and against euthanasia. British Journal of Medicine and Research 9, no. 7 2015: 3.

7 Ibid. 
legal problem. Even in all the countries that legalised euthanasia or physician assisted suicide, consent is the corner stone ${ }^{8}$ The practice of euthanasia may either be active or passive. The former is an act that causes the death of a patient like administering supra-therapeutic dose of morphine or lethal injection (potassium chloride), while the latter is withholding or withdrawing life-sustaining support or treatment to deliberately cause death. ${ }^{9}$

\section{Brief History of Euthanasia}

Many people think Euthanasia is a new phenomenon. This is far from being true. Euthanasia is as old as death itself, even though its history started from suicide. Perhaps the only thing that distinguishes the past and the present is the question of methodology and legalization. Debates about euthanasia has existed since long ago. It was found in the writings of the Greek and Roman scholars. ${ }^{10}$ The concept was common among them, but to them euthanasia did not mean hastening death; any peaceful, easy or happy death is euthanasia. ${ }^{11}$ Importance was attached to physical health. Even to Hippocrates, ${ }^{12}$ it was considered as something better than wealth and beauty. For that therefore, it was considered as an insult to gods for a person to commit suicide. ${ }^{13}$ But it was an acceptable act if one is physically challenged to commit suicide. Suicide was left in the hands of an individual in Greek and Roman belief, so physicians were allowed to hasten the death of a person having physical health challenges. ${ }^{14}$ Not until when Hippocrates and his followers started

\footnotetext{
8 Ayobami Samsong. Euthanasia: Socio-medical and legal perspective. International Journal of Humanities and Social Science 4, 2014.

9 Mcgee Andrew. http://eprints.qut.edu.au/66722/. Bioethics: Queensland University of Technology 29, no. 2, 2015, 74-81.

10 Hawkins M. Compulsory death: A historiographic study of the engenics and euthanasia movements in Nazi Germany, East Tennessee State University, 2010 p.114.

11 "A general history of euthanasia. A New Zealand report for life related issues, 2014, http://www.life.org.nz/euthanasia/abouteuthanasia/historyeuthanasia. Retrieved 1/1/2016.

12 Hippocrates is the writer of the famous Hippocratic Oath that serves as the ethical guide to medical doctors in their professional practice for over 1000 years.

13 Ibid.

14 Lan D. From Sander to Schiavo: Morality, partisan politics, and America's culture war over euthanasia, 1950-2010, Journal of Policy 21, 52013.
} 
giving modern ways of treatment that physicians started to question the acceptability of assisted suicide and euthanasia. ${ }^{15}$

During the second century, acceptability of euthanasia began to wane in Europe. Detesting euthanasia increased with the overwhelming dominance of Christians in the legal and moral thinking. Christian faiths detest suicide because life is considered sacred and suicides delay somebody's passage to life after death. It became serious when St. Augustine wrote clearly about the Catholic's stringent disbelieve in taking life even in extreme ill health and pain. However, during the $19^{\text {th }}$ century consideration for euthanasia started reemerging especially with the modern practice of medicine and technological advancement. ${ }^{16}$ These included advances in medical diagnosis and accurate prognosis assessment. Another important development during the $19^{\text {th }}$ century was the discovery of analgesic. Morphine could be used to manage pain and assist a dying patient. Physicians encouraged the use of it but detested giving an overdose, arguing that it could only be used to prolong life. These are the scientific developments that resurrected the debate for legalizing it in the $19^{\text {th }}$ century. ${ }^{17}$ Writers began to contribute to the debate, lawyers in the legal parlance and even physicians. Lawyers were arguing for euthanasia because of the too much control physicians had over their patients. Thereafter began the emergence of organizations and associations soliciting for the right to die, mostly in America. Notably among them: The Society for Right to Die with over 147,000 members and the World Federation of Societies for the Right to Die founded in $1980 .{ }^{18}$ During this period a number of judicial decisions were reached. Some of them will be highlighted in the later part of this paper.

Colonialism in Africa and the spread of the two dominant religions, Christianity and Islam disencouraged the struggle for euthanasia in Africa. ${ }^{19}$ Islam discourages and makes it an offence to makes

rosenfeld b. assisted suicide and the right to die: the interface of social science, public policy and medical ethics, Washington: American Psychological Association, 2004 p.205

16 Gorsuch M Neil. The future of assisted suicide and euthanasia (Princeton: Princeton University Press.20, 2006

17 Ibid.

18 Raymond W. A natural right to die: Twenty-three century of debate. Wesport Connecticut: Greenwood Press, 200225.

19 Oniha Eraze and Mabel Oniha Osato. Euthanasia and Assisted suicide as basic constitutional rights under the 1999 Constitution of Nigeria, p.7. 
any attempt to take anybody's life without the due process of law. Under Islamic law, only a tried and convicted person over certain offences is allowed to be killed. Several Qur'anic provisions confirmed the view of prohibiting anybody from taking an innocent life. "Do not take life, which Allah made sacred, other than in the course of justice," "If anyone kills a person -unless it is for murder or spreading mischief in the land - it would be as if he killed the whole people." In several other verses God shows that everybody has his own destined time of death; once such time is due no one will be spared. ${ }^{20}$ However, it must be remembered that prohibition of euthanasia in Islam is not absolute, because the passive aspect of euthanasia is allowed especially where the patient's life is only maintained on a life support without any hope of recovery. In this instance the scholars agreed that such life support can be withdrawn to allow the patient have his death naturally. One may say that the person dies of the natural consequences of his illness, but it is another view that he would not have died without removing the life support, and therefore removing it one way or the other contributed to the patient's death. This view continued even after the colonization among both the Muslims and the Christians. Therefore euthanasia is an unacceptable concept in Africa where the above mentioned religions have a dominant role. Although history has shown that it was practised in the Yoruba society of Nigeria where newborn twins, known as "Ibeji," were killed immediately after they were born. They were believed to be evil, monstrous abnormalities. ${ }^{21}$ The traditional practice of the Kikuyu community where a terminally ill patient was abandoned in the Bush with some food so that he may die by himself, was misconceived as euthanasia. ${ }^{22}$ It has to be noted that none of the above practices can be equated to Euthanasia. This is because none of the cases above was done for the interest of the victim or to relieve him from pain. However, practices by militaries in some countries, known as 'save our souls' are regarded as euthanasia, where soldiers captured by enemies are killed by their colleagues, to prevent them from revealing secrets and also to relieve them from suffering in the hands of the enemies. Their

\footnotetext{
20 Mehran Narimisa. Euthanasia in Islamic views. European Scientific Journal June 2, no. June 2014, 170-73.

21 Sakali F. The contemporary euthanasia debate in the light of african world view and ethics. SEGi Review (6), 5-15.

22 Ibid.
} 
colleagues, therefore, will bombard them all together. This is a form of assisted suicide or mercy killing as conceived by some scholars. ${ }^{23}$

\section{EUTHANASIA PRACTICE FROM OTHER JURISDICTION}

Any act of assisting suicide in the UK is a punishable offence particularly under Section 2 of the Suicide Act 1961. The Suicide Act was enacted in 1961 with the effect that any attempt to assist in a suicide mission is a crime ${ }^{24}$ but in the UK, the Assisted Dying Bill was before the House of Lords although it was unsuccessful. The Bill provided for a person over the age of 18 who was terminally ill and had six months or less to live to seek and lawfully be provided with assistance to die. ${ }^{25}$ It is still illegal because the Bill did not become law. ${ }^{26}$ Health workers prescribed the lethal medication and prepared it for administration. However, the individual would need to take the final act that would end his or her life by self-administering the medication. ${ }^{27}$

Although suicide is a crime in the US, nobody has ever been punished for it; besides who is to be punished when the murderer is the murdered? However there is a penalty for aiding and assisting another to commit suicide. Three states have legalised euthanasia, namely Oregon, Washington and Montana. For example, in the District court of Dorothy, the court accepted the Terminally Ill Bill, stating that all patients had the right to administer lethal doses of medication if prescribed by a physician and the physician was immune from prosecution.

In the Netherlands however, giving a person moral support to commit suicide is not an offence, so is also providing him with all the necessary information. This may be the reason Netherlands is one of the countries to first legalized euthanasia. ${ }^{28}$ At the same time, it was reported that

23 Abdul Haseeb Ansari, A O Sambo, and A B Abdulkadir. The right to die via euthanasia: An expository study of the of the Sharia and laws in selected jurisdictions," Advance in Natural and Applied Sciences (6), 2012673. UKSC. R (Nicklinson) v Ministry of Justice, 38 (2014), p.38

25 Jocelyn D. Permitting voluntary euthanasia and assisted suicide: Law reform pathways for common law jurisdictions," QUT Law Review (16), 2016 84, doi:10.5204/qutlr.v16i1.613.

26 EWHC. Nicklinson v MOJ [2013] EWCA Civ, 961.p.96.

27 Ibid.

28 NVVE, Dutch Right to Die Society, launches website about international films and documentaries like The Suicide Tourist, Terry Pritchett: Choosing to Die and A dignified End (an English spoken Dutch documentary on a right to a 
death via euthanasia in the Netherlands had also has increased from 1923 in 2006 to 3695 in $2011 .^{29}$

In Australia, research has shown that the majority of health workers wish to be allowed to actively end their patients suffering through euthanasia. A majority of nurses also support this idea while some would prefer to assist a terminally ill patient. Only a minority of palliative care nurses preferred to assist. ${ }^{30}$ The Northern Territory

Rights of the Terminally Ill Act ${ }^{31}$ enables a medical practitioner to assist to end a patient's life where the patient requesting it has a terminal illness diagnosed and confirmed by two medical practitioners, is experiencing pain, suffering and/or distressed to an extent unacceptable to him/her, and has been assessed by a psychiatrist to be of "sound mind" and not suffering from clinical depression. ${ }^{32}$ However, a research should be conducted to see the views and attitude of Nigerian doctors regarding euthanasia and to find out their attitude of the issue of patients who are in an irreversible coma or a permanent vegetative state.

\section{LEGAL IMPLICATION OF WITHDRAWING OF TREATMENT AND OTHER LIFE-SUPPORTING MACHINES AND EUTHANASIA IN NIGERIA}

Withdrawing, withholding medical treatment or life support happens when it becomes a burden or an exercise in futility, extending only the life of the patient when he continues to suffer. The withdrawal is done to hasten the patient's death assuming it to be from the

dignified end) Besides that, there is an official website "This is the End" which is a gathering ground of background information on international documentaries and films regarding the subject of voluntary end-of-life decisions.

29 Schadenberg A. Euthanasia is out of Control in the Netherlands - New Dutch Statistics," http://www.lifesitenews.com/blog/euthanasia-is-out-of-control-inthe-netherlands-new-dutch statistics, 2015 8/4/2016

30 a Sanson et al. Psychological Perspectives on Euthanasia and the Terminally Ill: An Australian Psychological Society Discussion Paper," Australian Psychologist (33) 1998 1-11, doi:10.1080/00050069808257255.

31 Johan Materstvedt, "Euthanasia and Physician-Assisted Suicide: a View from an EAPC Ethics Task Force" http://www.cuidadospaliativos.org/archives/Euthanasia\%20and\%20 physician-assisted\%20suicide.pdf 18/4/2016.

32 Ibid. 
natural consequences of his illness. They include ventilation, renal dialysis and chemotherapy for cancer patients and administration of artificial nutrition and hydration. ${ }^{33}$ Whatever name it may be given the end result will be death, because patient's life would have been sustained if not for withdrawing the support. This would have been resolved after a thorough analysis of the concept of death, when does death occur and how it can be ascertained, only then will one know whether if you withdraw the support the person can continue to live or will die. ${ }^{34}$

However, it will interest readers of this piece to know, that modern Islamic jurists agree that it is not good for a doctor to keep prolonging the life of a patient that is scientifically ascertained to be in an irreversible coma or in a permanent vegetative state with no hope of recovery; ${ }^{35}$ adding that it is the process of life that doctors seek to maintain and not the process of dying. However, as we shall come to see in this paper any such act is a crime in Nigeria. We shall see how the Nigerian criminal law will look at this situation.

It is trite that suicide is not a crime under the Nigerian legal system. However, aiding and abetting the commission of suicide is a punishable offence in the country. ${ }^{36} \mathrm{I}$ will rather add here that anybody attempting to kill himself is not supposed to be punished, but the cause should be investigated, because it is obvious most people attempting suicide need to see a psychiatric doctor and be given some form of rehabilitation or other therapy. Now it will be assumed that where a physician, on the request of a terminally ill patient, prescribes drugs to hasten the death of that patient he shall be guilty of aiding and abetting the offence of suicide. No case has been decided in Nigeria on this issue though, but it is this writer's opinion that it will amount to abetting suicide if the soul intention is to cause the death of that patient notwithstanding the motive is

33 Kassim Puteri J. and Adeniyi Bashiru. Withdrawing and Withholding Treatment: A Comparative Study Between the Malaysian, English and Islamic Law," Medlaw 2010 (29) 1.

34 MacMahan Jeff. The Ethics of Killing: Problems of the Margin of Life. New York: Oxford University Press, 45.

35 Adebayo R. Ibrahim. Euthanasia in the Light of Islamic Law and Ethics, Journal of the Nigeria Association of Teachers of Arabic and Islamic Studies (11) 2008 1-12, doi:10.1017/CBO9781107415324.004.

36 Section 36 Criminal Code (Nigeria, 2004.). 
good or is to relieve the patient from the agony of illness. The penal system and medical code of ethics will not accept any attempt to assist any patient to die or hasten his death. Consent or good motive has never been a defense to crime in the Nigerian legal system.

The above position will be slightly different under the doctrine of Double Effect, ${ }^{37}$ where pain relieving drugs are administered by a physician with the intention of getting relief from pain, and is very well known to the physician that the resulting effect may be to hasten death, although death is not intended. ${ }^{38}$ This medical practice is largely recognized and is practiced without any legal implication. But can this practice be acceptable in Nigeria for example? The legal systems will not accept any act that the doer of the act has knowledge that the likely consequences of his action will be death. ${ }^{39}$ Let us have a brief discussion of the laws in Nigeria.

In Nigeria an act of crime includes commission or omission..$^{40}$ Nobody cares who is behind the act or the omission, whether physician or an interloper. Any act or omission that has the result of causing death will be a crime. What will however, require investigation is whether the withdrawal of life support or treatment of a terminally ill patient will amount to an omission within the ambit of law to constitute the offence of murder, noting the difference from where the treatment started and withdrawn and where it was not started. For the purposes of analysis I will reproduce the provision of the both Penal Code and the Criminal code respectively.

37 The Doctrine is an action involving foreseen harmful effects which cannot be avoided if the desired good effect is to be achieved may be justified as long as the following criteria are satisfied: (1) The basic act is, when considered independently of its bad effect, not wrong or at least morally neutral. (2) The agent intends the good effect, and does not intend the bad effect either as an end in itself or as a means to the good. (3) The circumstances in which the agent must act are sufficiently grave as to justify causing the bad effect, and the agent exercises due diligence to minimize the harm. Shane N Glackin and Simon Mills, "Termination of Pregnancy", Article 40 .3 .3 $\square$, and the Law of Intended Consequences I - Introduction Responding, in December 2012, to the Government 'S Decision to Legislate for A . G .” 3, December 2012 (2013): 76. Ibid.

39 Section 221 Penal Code, Penal Code (2004).

40 In an enactment the following expressions have the meaning hereby assigned to them respectively, that is to say-An act includes or omission, and reference to the doing of an act shall be constituted accordingly. Section 18 (1) Interpretation Act, Cap J1 Laws of the Federations of Nigeria 2004. 
Section 220 Penal Code: Whoever causes death-

(a) by doing an act with the intention of causing death or such bodily injury as is likely to cause death; or

(b) by doing an act with knowledge that he is likely by such act to cause death; or

(c) by doing a rash or negligent act, commits the offence of culpable homicide.

With a careful perusal of the above provisions of the law, an offence of homicide can be committed only by an overt act, causing death or grievous body injury, so long as the doer of the act has knowledge that his action is likely going to cause death. Omission is not included as a means of committing an act of murder by the above provision. One will have thought that omitting to save the life of a patient by a physician cannot constitute the offence of homicide under both Penal Codes. Although generally whenever an act is said to be a crime the likely interpretation is that the act will include omission. ${ }^{41}$ For example, in this article, refusing medical treatment

where administering the same is an exercise in futility is an omission act which may cause death, although one may argue that the patient here will only die because of the natural consequences of his illness. ${ }^{42}$

However, under the Northern Nigerian penal code, a provision is inserted to show that whenever an act is said to be an offence, whatever effect that act may cause, if omission to act will cause the same effect it will be deemed to constitute the same offence:

Section 26 provides:

Wherever the causing of an effect or an attempt to cause that effect by an act or by omission is an offence it is to be understood that the causing of the effect or the attempt to cause that effect partly by an act or partly by an omission is the same offence. ${ }^{43}$

Therefore, in all ramification, euthanasia, is a crime in Nigeria although the law leaves much to be desired compared to the provision

41 Ibid.

42 Manalo Maria C. Fidalis. End-of-Life Decision about Withholding or Withdrawing Therapy: Medical,ethics, and Religion-Cultureal Consideration, 2014.

43 Section 26, Penal Code. 
of the Criminal code regarding euthanasia, because the penal code does not anticipate euthanasia as an acceptable phenomenon or something that will be an issue in the society where it operates. The criminal code makes elaborate provisions in making euthanasia and assisted suicide a crime.

Section $308^{44}$ provides:

Except as hereinafter set forth any person who causes the death of another, directly or indirectly, by means of whatever, is deemed to have killed that person..."

In section 311 the code provides:

A person who does any act or makes any omission which hastens the death of another person who, when the act is done or the omission is made, is laboring under some disorder or disease arising from another cause is deemed to have killed that other person.

A more relevant provision of the Criminal Code Section 316 says,

Except as hereinafter set forth, a person who unlawfully kills another under any of the following circumstances, that is to say....

5) death is caused by administering any stupefying or over powering things for either of the purposes last aforesaid;

6) if death is caused by willfully stopping the breath of any person for either of such purpose is guilty of murder, is immaterial that the offender did not intend to cause death or did not know that death was likely to result.

In voluntary euthanasia one may ask, what happens where the act or omission is done with the consent of the victim. In other words is voluntary euthanasia allowed? The law says that free will or consent or even compassion towards the victim will never be an excuse to the euthanasia perpetrator. Section 299 provides:

Consent by a person to the causing of his own death does not affect the criminal responsibility of any person by whom such death is caused.

44 Criminal Code Cap C38 Laws of the Federation of Nigeria 2004. 
In addition to this, Section 326 of the Criminal code provides:

1) any person who procures another to kill himself; or

2) as stated earlier the provision of the criminal code is more encompassing, because the use of the word directly or indirectly will include all acts or omission from the part of a physician to hasten death by whatever means, be it through overdose of morphine, lethal injection or withdrawal of ventilator and respirators. Section 311 specifically talks about on the patient laboring on any kind of disorder or disease. This is directly referring to euthanasia both passive and active. Most particularly Section 316 which directly relates to the withdrawal of ventilator that keeps a patient breathing. Therefore withdrawal of such ventilation is termed as passive euthanasia and it is crystal clear to be a crime. However, a number of decisions outside Nigeria acknowledged this situation not to be a crime so long as the withdrawal is done with consent of the patient or it is done in his best interest. ${ }^{45}$ Besides, there are other provisions in the criminal code that are more direct to prohibit euthanasia. One may assume that still the provision of the criminal code addresses directly or counsels another to kill himself and thereby induces him to do so; or

3) aids another in killing himself; is guilty of a felony and is liable to imprisonment for life.

This is followed by the code of conduct of the medical and dental practitioners on saving life and prohibiting letting or assisting death. ${ }^{46}$ Any physician who does so will be guilty of breaching the code of conduct if he: terminates a patient's life by prescribing lethal drugs notwithstanding the patient's request, allows the patient to terminate his life by prescribing the drugs or without his request, but for his best interest. The punishment under the rules is to suspend or withdraw the practice license, at the same time the physician may be found guilty of murder and appropriately punished. ${ }^{47}$

\footnotetext{
45 EHRR, Herczegfalvy V. Austria, 15437 (1993).

46 Rules 68 Code of Medical Ethics, "Practitioners, Rules of Professional Conduct For Medical \& Dental," 2004.

47 Abimbola O. "Law and Medicine: A Meeting Point," Research. Journal of Health Science (2) 2014192
} 
The pertinent question one will be forced to ask is that, sometimes a patient can be in such a condition that he is not dead, but he is better off dead, especially if the quality of life is so bad. ${ }^{48}$ This makes treatment to be abandoned. Although it is somebody's opinion that the quality of life is bad, it is based on whether the patient is worthy of the treatment rather than whether the treatment will improve or extend his life. In such a situation treatment is withdrawn and it will hasten death. By the provision of the criminal code or even the penal code of Nigeria any physician who does such an act will be guilty of a crime. ${ }^{49}$ However, in some jurisdiction such situation is not considered as murder. ${ }^{50}$ But death will be taken to be the natural consequences of his illness because the patient would have died even without the withdrawal of such supporting machine or treatment.

The situation will be complex if the patient claimed that it is his human right to refuse and withdraw from any treatment, even if that will lead to his death. In this situation a question of priority will arise. Is it the right of the patient, professional ethics or criminal law? It is this writer's opinion that the human right of the patient shall be considered first. The Nigerian Supreme Court opined that a patient has the right to refuse medical treatment even if that will lead to his death. ${ }^{51}$ However, notwithstanding the right of the patient, the health workers also have the right to consider their moral values, whether in principle they agree to assist somebody to die or their religious belief will accept the practice. ${ }^{52}$

48 Ralf Stutzki et al. "Attitudes towards Hastened Death in ALS: A Prospective Study of Patients and Family Caregivers," Amyotrophic Lateral Sclerosis \& Frontotemporal Degeneration (15), 68-76, doi:10.3109/21678421.2013.83792 8 .

49 Ansari, Sambo, and Abdulkadir. "The Right to Die Via Euthanasia: An Expository Study of the of the Sharia and Laws in Selected Jurisdictions." Advances in Natural and Applied Sciences, (6) 201223.

50 Airedale NHS Trust V. Bland, 789 (1993).

51 LPPELR, Medical and Dental Practitioners Disciplinary Tribunal v. John Emewulu Nicholars Okonko, 2131999 (2001).

52 Lachman D. Vicki. "Voluntary Stopping of Eating and Drinking: An Ethical Alternative to Physician-Assisted Suicide", Ethics, Law and Policy, (22) 2015 57. 


\section{CONSEQUENCE OF AMENDING THE LAW TO LEGALISE EUTHANASIA}

Like other issues euthanasia has it is pros and cons. In countries where the legal system does not pave the way for its practice, many supporters will be calling for the laws to be amended because they are blindfolded to the benefit to be derived from its legality. The following is a brief discussion of the danger of legalizing euthanasia.

Slippery slope is one of the arguments of the antagonists of euthanasia. They term its legalization as a downhill movement, which will affect other vulnerable members of the society, moving from voluntary to involuntary. The government will not be able to control its abuse. This argument is true because research has shown that eight controversial euthanasia cases were discovered. One of them was a convicted rapist and a prisoner who was killed through lethal drugs because his life was full of regret and disturbance and his death led to fifteen more prisoners. ${ }^{53}$ Other cases involved twin deaf brothers who were diagnosed to go blind. They were euthanized because they could not bear the difficulties of not seeing each other. Initially the law was meant for those with terminal illness and in extreme pain, but other categories are benefitting, which ordinarily they would not have benefited from the framework because their cases did not qualify as terminal illness. ${ }^{54}$

Passive euthanasia is by way of withdrawing the life supporting machine and treatment where the exercise becomes fruitless; ${ }^{55}$ however, because there is no certain measurement or instruments to determine when death will occur, many patients live for long time before they finally die after the withdrawal. ${ }^{56}$ Some may stay up to a week or two and unfortunately throughout the period they are in a state of aguish and extreme pain. Therefore, if the reason for allowing passive euthanasia is to relief patients from pain, it will be reasonable to allow active euthanasia where death could be hastened and the pain would be reduced if not removed completely.

53 Murano Grace. "8 Most Controversial Cases of Euthanasia," Bizarre Medical Stories, 2015, http://www.oddee.com/item_99258.aspx.

54 Ibid.

55 Airedale NHS Trust V. Bland, 789 (1993).

56 James Lucy Elisabeth. The Withdrwal of Treatment: Working Paper in the Health Science, 1, 2014. 
Legalizing euthanasia will do serious damage to our most important institutions, law and medicine. Law will lose its respect if it becomes an instrument of destroying rather than protecting life because Africans or Nigerians do not like death. In medicine, if doctors are allowed to take their patient's life, the great danger this will bring cannot be over emphasized. Patients will never want to be in the hospital for fear of becoming a victim; the trust between doctors and their patients will erode with time and the fundamental values of the society will be destroyed. ${ }^{57}$ Keown has this to say:

"In 30 years, the Netherlands has moved from euthanasia of people who are terminally ill, to euthanasia of those who are chronically ill; from euthanasia for physical illness, to euthanasia for mental illness; from euthanasia for mental illness, to euthanasia for psychological distress or mental suffering and now to euthanasia simply if a person is over the age of 70 and "tired of living." 58

\section{CONCLUSION}

This paper gives an insight of the inadequacy of the provision of the law regarding euthanasia in Northern Nigeria where the Penal Code applies, even though in Nigeria there are two criminal laws, the Criminal Code and the Penal Code. The two laws are operating in different parts of Nigeria; one with sufficient provision and the other not so adequate. The insufficient law here is the Penal Code applicable in northern Nigeria. The most important area of concern is the issue of withdrawing treatment and other life support, or giving sedative drugs that have the implication of hastening death. As far as the law is concerned any act or omission resulting in death will amount to a crime although it may not be so in some other common law countries. The point is recognition of the doctrine of double effect and whether physicians will be excused because of their intention and not for the knowledge they have of the likely consequences of their actions. Many scholars suggested that instead of amending the

57 Margaret Somerville. McGill Centre for Medicine, Ethics and Law by La Commission de La Santé et Des Services Sociaux Du Québec Consultations Auditions Publiques Sur Le Projet de Loi $N^{\circ} 52$, Loi Concernant Les Soins de Fin de Vie, 2013.

58 Keown J. Euthanasia, Ethics, And Public Policy: An Argument Against Legalisation. New York: Cambridge University Press, 200224. 
law to permit any act of taking life to relieve pain, hospice houses and palliative care should be encouraged. Most importantly legalizing euthanasia will not encourage the development of palliative care as an alternative to euthanasia, although palliative care could be more expensive than some of the therapies given to patients with terminal illness.

\section{BIBLIOGRAPHY}

A General History of Euthanasia. A New Zealand Report for Life Related Issues. Retrieved from http://www.life.org.nz/ euthanasia/abouteuthanasia/historyeuthanasia

Airedale NHS Trust V. Bland, 789, 1993.

Andrew, M. (2015). Acting to let someone die. Bioethics, 29(2), 7481. Retrieved from http://eprints.qut.edu.au/66722/.

Ansari, Abdul Haseeb, A. O. Sambo, \& A. B. Abdulkadir. (2012). The right to die via euthanasia: An expository study of the of the sharia and laws in selected jurisdictions. Advance in Natural and Applied Sciences, 6(5), 673-81.

Barry, R. (2004). Assisted suicide and the right to die: The interface of social science, public policy and medical ethics. Washington: American Psychological Association.

Bioethics, Centre for "End of Life Care: An over view," (2005).

Code, Penal. Penal Code. Nigeria, (2004).

Craig, P. (2008). Assisted suicide and euthanasia: A natural law ethics approach. Cornwall: TJ International Limited.

Criminal Code. Nigeria, (n.d.)

Dowbeggin, L. (2013). From Sander to Schiavo: Morality, Partisan Politics, and America's Culture War over Euthanasia, 19502010. Journal of Policy, 21(13), 5.

Downie, J. (2016). Permitting voluntary euthanasia and assisted suicide: Law reform pathways for common law jurisdictions. QUT Law Review, 16(1), 84. doi:10.5204/qutlr.v16i1.613

EHRR. (1993). Herczegfalvy V. Austria, 15, 437.

Elisabeth, J. L. (2014). The withdrawal of treatment. Working Paper in the Health Science, 1(6)

EWHC. (2012). Nicklinson v MOJ.

Fidalis, Manalo Maria C. (2013). End-of-life decision about withholding or withdrawing therapy: Medical, ethics, and religion-cultureal consideration. Palliat Care, 7, 1-5. 
Glackin, S. N., \& Simon, M. (2013). Termination of Pregnancy, Article $40.3 .3^{\circ}$, and the Law of Intended Consequences. Irish Journal of Legal Studies, 3(3), 76 - 91.

Grace, M. (2015). Most Controversial Cases of Euthanasia. Bizarre Medical Stories. Retrieved from http://www.oddee.com/ item_99258.aspx.

Hawkins, M. C. (2010). Compulsory Death: A Historiographic Study of the Eugenics and Euthanasia Movements in Nazi Germany. Electronic Theses and Dissertations. Paper 1707. https://dc.etsu.edu/etd/1707

Ibrahim, A. R. (2008). Euthanasia in the light of islamic law and ethics. Journal of the Nigeria Association of Teachers of Arabic and Islamic Studies, 11, 1-12. doi:10.1017/ CBO9781107415324.004.

Jahn Kassim, Puteri Nemie \& Omipidan, Bashiru Adeniyi. (2010). Withdrawing and witholding medical treatment: A comparative study between the Malaysian, English and Islamic law. Medicine and Law Journal, 29(3), 443-461.

Jeff, M. (2002). The ethics of killing: Problems of the margin of life. New York: Oxford University Press.

Keown, J.(2002). Euthanasia, ethics, and public policy: An argument against legalisation. New York: Cambridge University Press

Lachman, V. D. (2015).Voluntary stopping of eating and drinking: An ethical alternative to physician-assisted suicide. MEDSURG Nursing, 24(1), 56-59

LPPELR. Medical and Dental Practitioners Disciplinary Tribunal v. John Emewulu Nicholars Okonko, 213 1999, 2001.

Michael, Hawkins. (2010). Compulsory Death: A Historiographic Study of the Eugenics and Euthanasia Movements in Nazi Germany. East Tennessee State University.

Nagus, Ebrahim. (2012). The ethics of euthanasia. Australian Medical Student Journal, 3(1), 2.

Narimisa, Mehran. (2014). Euthanasia in Islamic views. European Scientific Journal June, 2, 170-73.

Neil, G. M. (2006). The future of assisted suicide and euthanasia. Princeton: Princeton University Press.

O, Abimbola. (2014). Law and medicine: A meeting point. Research Journal of Health Science, 2(4), 192. 
Osato, Oniha Eraze, \& Mabel Oniha. (2015). Euthanasia and Assisted Suicide as Basic Constitutional Rights under the 1999 Constitution of Nigeria. Nigerian Law Guru, 20.

Paul, B. (2008). Patient's right law and ethics for nurses: A practical guide. London: Hdder Education.

Rules of Professional Conduct for Medical \& Dental Pratitioners. Nigeria, 2004.

Sakali, F. (2013). The contemporary euthanasia debate in the light of african world view and ethics. SEGi Review, 6, 5-15.

Samsong, A. (2014). Euthanasia: Socio-medical and legal perspective. International Journal of Humanities and Social Science, 4.

Sanson, A., Dickens, E., Melita, B., Nixon, M., Rowe, J., Tudor, A., \& Tyrrell, M. (1998). Psychological perspectives on euthanasia and the terminally ill: An Australian Psychological Society discussion paper. Australian Psychologist, 33(1), 1-11. doi:10.1080/00050069808257255.

Schadenberg, A. (2015). Euthanasia is out of control in the Netherlands - New Dutch Statistics. Retrieved from http:// www.lifesitenews.com/blog/euthanasia-is-out-of-control-inthe-netherlands-new-dutch statistics

Somerville, M. (2013). McGill Centre for Medicine, Ethics and Law by La Commission de La Santé et Des Services Sociaux Du Québec Consultations Auditions Publiques Sur Le Projet de Loi $N^{\circ} 52$, Loi Concernant Les Soins de Fin de Vie.

Stutzki, R., Weber, M., Reiter-Theil, S., Simmen, U., Borasio, G. D., \& Jox, R. J. (2014). Attitudes towards hastened death in ALS: A prospective study of patients and family caregivers. Amyotrophic Lateral Sclerosis \& Frontotemporal Degeneration, 15(1-2), 68-76. doi:10.3109/21678421.2013. 837928

UKSC. R (Nicklinson) v Ministry of Justice, 38 (2014).

Visnja, S. (2015). Argument in support and against euthanasia. British Journal of Medicine and Research, 9(7), 3.

Whitting, R. (2002). A natural right to die: Twenty-three century of debate. Wesport Connecticut: Greenwood Press.

World Health Organisation. (2004). A glossary of terms of community health care and services for older persons. 